\title{
WILEY
}

\section{Journal of Economics}

Om arbetareförsäkring

Author(s): N. V. E. Nordenmark

Source: Ekonomisk Tidskrift, Årg. 1 (1899), pp. 300-305

Published by: Wiley on behalf of The Scandinavian Journal of Economics

Stable URL: http://www.jstor.org/stable/3436880

Accessed: 27-06-2016 03:23 UTC

Your use of the JSTOR archive indicates your acceptance of the Terms \& Conditions of Use, available at

http://about.jstor.org/terms

JSTOR is a not-for-profit service that helps scholars, researchers, and students discover, use, and build upon a wide range of content in a trusted digital archive. We use information technology and tools to increase productivity and facilitate new forms of scholarship. For more information about JSTOR, please contact support@jstor.org.

Wiley, The Scandinavian Journal of Economics are collaborating with JSTOR to digitize, preserve and extend access to Ekonomisk Tidskrift 
angifves. Och det är ju endast de mindre likviderna, som skola regleras på detta sätt. Styrkan hos all en banks inlåning ligger som bekant däri, att den har en mängd insättare, konti, hvart och ett å mindre belopp.

De egentliga sparbanksmedlen böra, enligt mitt förmenande, icke öfvergå till bankerna. Men jag undrar, om den nya lagen skall visa sig vara effektiv och verka såsom statsmakterna tänkt sig. Intet $\mathrm{i}$ gällande lag kan hindra bankerna att för sina kunder öppna giroräkningar med begränsad uttagnings-rätt och -tid. Detta skall väl tiden visa. -

Meningen har från min sida endast varit den, att framhålla, huru denna rörelsegren kommit till oss och hur den här utvecklar sig i förening med checksystemet, och jag kan icke se annat än att näringslifvit har gagn däraf, såvida endast bankerna begränsa sin klientel och icke komma sparbankerna för nära. Säkert är, att en del penningar, som eljes ligga på kistbotten, på sådant sätt komma till bankerna, hvilket kan ha sin stora betydelse, när Riksbanken en găng öfvertager hela văr sedelemission, ity att allmänheten efter hand har vant sig vid checksystemet och följaktligen lärt sig att ha sina penningar i bankinrättning.

Då nu, såsom angifvits, en praxis redan utbildat sig vid begagnandet af hushålls- eller sparkasseräkning i förening med checksystemet, förefaller det mig vara en onödighet, att lagstiftningen söker att ytterligare reglera denna affärsrörelse, som, rätt bedrifven, icke bör kunna tränga in pă sparbankernas verksamhetsområde.

Det skall nämligen fasthållas, att bankerna böra söka att förvärfva endast sădana kunder, som eljes icke hălla bankräkning, och om sparkasserörelsen utvecklar sig i denna riktning, bör den här angifna synpunkten vara den riktiga och rörelsen sund.

Den nya lagen stadgar visserligen en veckas uppsägning, men denna är väl närmast en säkerhetsåtgärd, som kan tillämpas af bankerna under vanskliga tider.

A. S. P.

\section{Om arbetareförsäkring.}

Ett af samtidens mest brännande och svårlösta sociala problem torde helt säkert det vara att på ett praktiskt och billigt sätt anordna försäkring för arbetare. Statens skyldighet att taga frågan om hand och skaffa arbetaren skydd vid inträffadt olycksfall eller vid arbetsoförmåga på ålder- 
domen torde numera vara fullständigt erkänd, och det är väl endast om sättet att ằstadkomma en dylik försäkring striden gäller. I vårt land, som i försäkringstekniskt hänseende för öfrigt står synnerligen högt, har dock ännu ej gjorts năgot egentligt för att åstadkomma en obligatorisk statsförsäkring af arbetare.

I det hänseendet äro vi långt underlägsna nästan alla Europas kulturfolk. På hvilket sätt emellertid än staten en gång lyckas lösa denna sin uppgift, så kommer likväl alltjämt att förefinnas och återstå en stor uppgift för den privata försäkringsverksamheten, den nämligen att tillvarataga de arbetande klassernas små besparingar för att på lämpligaste sätt göra dem fruktbringande för ålderdomen eller för de efterlefvande.

Talrika försök att åstadkomma en dylik välsignelsebringande försäkringsverksamhet ha ock gjorts $\mathrm{i}$ de stora kulturlanden, framför allt $\mathrm{i}$ England. Det förnämsta arbetareförsäkringsbolaget i detta land, Prudential Ass. C:o, grundades år I848. Vid I897 års slut uppgick de försäkrades antal i de engelska arbetareförsäkringsbolagen till I5,860,654 för en försäkringssumma af 2,737,378,742 kr. Med ej mindre intresse har arbetareförsäkringen omfattats i Tyskland.

Det system, som af bolag i dessa länder hufvudsakligen användts, bestăr i upptagande af en viss afgift, växlande mellan to öre och I kr. i hvarje vecka eller i hvarje månad. Năgon läkareundersökning ifrågakommer ej, emedan detta skulle vara för dyrbart, och dessutom är det vanligen förenadt med svårigheter att få arbetare att underkasta sig en dylik. I stället erfordras vanligen ett intyg af trovärdiga personer, att den försäkringssökande för tillfället är frisk; dessutom stipuleras en viss karenstid, som växlar i olika land och bolag. I Prudential făs hela försäkringssumman ut först om 10 år efter försäkringsaftalets ingående; inträffar dödsfallet fullt 5 år efter inträdet, afdragas $50 \%$. Dör den försäkrade inom de tre första månaderna utbetalas blott $1 / 4$ och, om han dor efter tre månader, men inom ett år, erhåller rättsinnehafvaren blott hälften af det, som utbetalas efter ett års förlopp; vid dödsfall genom olyckshändelse utbetalas alltid hela försäkringssumman. I Victoria zu Berlin återbetalas endast de erlagda premierna vid dödsfall under det första försäkringsåret, under andra året hälften af försäkringssumman och först sedermera hela beloppet. I Schweizerische Versicherungs- und Rentenanstalt i Zürich gälla följande bestämmelser; dör den försäkrade af akut sjukdom eller på grund af olycksfall, utbetalas hela försäkringsbeloppet, oberoende af huru lång eller kort tid han varit försäkrad. Är sjukdomen kronisk, hvartill anlag kunna hafva funnits redan 
vid försäkringens tagande, återlämnas endast premierna, om döden inträffar under första försäkringsåret; under andra och tredje året utbetalas i dylika fall resp. $1 / 3$ och $2 / 3$ af försäkringsbeloppet. Sedermera utbetalas i hvarje fall hela summan.

Det numera vanligaste sättet för upptagandet af premierna är försäljning af sparmärken, som af den försäkrade uppklistras på ett kort, som månads- eller kvartalsvis insändes till försäkringsanstalten.

Emellertid kunna åtskilliga delvis svåra anmärkningar göras mot detta försäkringssätt. Den mest grava bland dessa är den, att metoden visar sig i hög grad dyrbar. Det är en dyr apparat, som ständigt măste vara i gång för att indrifva dessa små veckopremier. I det förut omnämnda engelska bolaget Prudential uppgå de årliga utgifterna till nära hälften $\left({ }^{7} / 16\right)$ af premieinkomsten, och $\mathrm{i}$ mindre bolag ha omkostnaderna visat sig stiga ända till $60 \%$. Detta är ju en synnerligen mörk sida hos en sak, som vill vara välsignelsebringande. De ständigt ăterkommande premiebetalningarna verka tröttande på de försäkrade, hvilka ju dessutom tillhöra de lager af befolkningen, som esomoftast byta om vistelseort. Svårigheter förefinnas sålunda så väl för den försäkrade att ständigt inbetala som för anstalten att ständigt utkräfva dessa oupphörligt ăterkommande små premier. Affallet har därför ock visat sig vara synnerligen stort, ett förhållande som ju ej talar till försäkringssättets förmån.

I stora samhällen, i arbetarecentra m. m. kan dylik försäkring möjligen drifvas med större framgång, emedan anstalten på sådana ställen kan ha råd att anställa särskilda indrifvare af premierna, hvilka härigenom säkrare inkomma. Det är därför klart, att i små land andra former för arbetareförsäkring jämsides med den anförda måste uppfinnas, om något varaktigare resultat skall kunna ernås. Denna nyss anförda arbetareförsäkring efter engelskt mönster har i Sverige drifvits bland andra af svenska Arbetarelifförsäkringsbolaget Valand, som efter fem års arbete ej kommit till högre försäkringssumma än 4,100,000 kr.

Flere förslag ha ock framställts $i$ och för erhăllande af billigare metoder för inkassering af de små veckopremierna. Schweizerische Versicherungs- und Rentenanstalt har lyckats göra en öfverenskommelse med regeringen, att postverkets frimärken kunna användas. Härigenom har en del omkostnader bortfallit, som förorsakas af försäljning af sparmärken och kontrollen häraf. Frimärken klistras nu på sparkortet, som sedermera inlöses af postverket.

I England existerar sedan åtskilliga år en s. k. postförsäkring, till 
sin idé af samma art som postsparbanken. Emellertid har den ej vunnit någon större anslutning, beroende nästan uteslutande därpă, att den ej dritver någon reklam eller äger năgra agenter.

Ett snarliknande förslag att försäkra medels frimärken framställdes i den danska Nationalökonomisk Tidskrift för 1896 af v. Kiørboe, men har, så vidt jag vet, ej vunnit någon efterföljd.

Det är klart, att själfva svårigheten att åstadkomma en lycklig lösning af denna sak till båtnad så väl för försäkringstagaren som anstalten ligger just uti att finna ett billigt och bekvämt sätt att uppsamla premierna. Försitter den försäkrade sin respittid för premieinbetalningen, så är försäkringen förfallen, och alla de fördelar, han genom densamma velat bereda sig, äro till större delen förlorade.

En försäkringsform, som i vissa afseenden är synnerligen lycklig och löser problemet på ett åtminstone för vissa försäkringstagare behagligt sätt, infördes i fjol af Allgemeine Deutsche Versicherungs Verein i Stuttgart, och har i år upptagits af Lifförsäkringsbolaget Svecia i Stockholm.

Detta försäkringssätt bestăr i upptagande af $\mathrm{s}$. k. engångspremier, huru små som helst. Den försäkrade är härigenom ej förpliktad till en fortlöpande, ständigt lika årspremie, utan inbetalar genom inköp af sparmärken endast så ofta och så mycket han vill. De gjorda insatserna betraktas sălunda som engångspremier. Följaktligen är han ej försäkrad för en på förhand bestämd summa utan blott till det belopp, som motsvarar de gjorda insättningarna, betraktade som engångspremier. Det blir härigenom möjligt att lämpa inbetalningarne för försäkringarna efter de tillfälliga omständigheterna , på arbetsmarknaden. Är förtjänsten god, kan han göra en större insättning, är den liten, så kan han göra en mindre eller ingen insats. Försäkringssättet är närmast att jämföra med postsparbankens sätt att mottaga små besparingar. En fördel, som genast, bör framhållas är den, att en dylik försäkran ej kan förfalla. För personer, för hvilka en ständigt återkommande förfallodag är oläglig vare sig på grund af naturell eller ekonomi, måste detta sätt att betala premierna vara synnerligen angenämt.

Någon läkareundersökning kan naturligtvis ej ifrågakomma, men măste ansökan om försäkring åtföljas af intyg om den försäkringssökandes hälsa af tvänne trovärdiga personer. Vid dödsfall betalas endast det försäkringsbelopp, som varit $\mathrm{i}$ gällande kraft $\mathrm{i}$ minst 6 mănader; de under de senaste 6 månaderna före dödsfallet gjorda insatserna ăterbetalas däremot. Om en försäkrad under 2 år icke gjort någon inbetalning, så måste han, innan nästa inbetalning sker, förete ett friskbetyg. 
För att skaffa anstalten säkerhet för att ej på detta sätt erhålla för stora risker, măste stipuleras, att de årliga inbetalningarne ej få öfverstiga en viss maximisumma, liksom ock försäkringssumman ej bör fă öfverstiga exempelvis 2,000 kronor. Afgifterna betalas genom köp af sparmärken, som uppklistras pă sparkort.

Sparkort, å kvilka märken äro fastsatta till ett belopp af minst 5 kr., skola vid början af nästa kvartal ( $\mathrm{r}$ jan., I april, I juli och I oktober) insändas direkt till anstalten eller till agenten, då däremot kort å mindre belopp endast mottagas den $\mathrm{r}$ juli.

Å den på de gjorda inbetalningarna beroende försäkringssumman tillställes den försäkrade ett försäkringsbesked, som bilägges försäkringsbrefvet.

$\AA$ hvarje nytt besked upptages därjämte den på grund af de tidigare beskeden försäkrade summan, så att det sist utfärdade försäkringsbeskedet alltid lyder på hela försäkringsbeloppet.

Den I juli hvarje år måste den försäkrade obetingadt aflämna hvarje sparkort, äfven dem å hvilka ännu icke fullt 5 kronor äro inbetalda. Belöper sig inbetalningen å ett kort till minst 3 kronor, să beräknas försäkringssumman såsom ofvan är angifvet, hvaremot vid en inbetalning af mindre än 3 kronor beloppet därpå öfverföres till ett nytt sparkort såsom förutbetalning för det kommande året.

Vi lämna här exempel för vissa åldrar på premierna för detta försäkringssätt vid vanlig lifförsäkring på lifstid, beräknade enligt svenska dödlighetstabellen $188 \mathrm{I}-\mathrm{I} 890$ och med en räntefot af $3^{1 / 2} \%$ samt belastade med hänsyn till de omkostnader, som detta försäkringssätt torde kräfva.

För en krona i engångspremie erhåller den försäkrade, om ansökan inlämnas:

$\begin{array}{cccc}\text { i en ålder af } & \text { en försäkringssumma af } \mathrm{kr} . & \text { i en ålder af } & \text { en försäkringssumma af } \mathrm{kr} \text {. } \\ 20 & 3: 24 & 30 & 2: 64 \\ 2 \mathrm{I} & 3: \mathrm{I} 7 & 3 \mathrm{I} & 2: 59 \\ 22 & 3: \text { I I } & 32 & 2: 53 \\ 23 & 3: 05 & 33 & 2: 47 \\ 24 & 3: 00 & 34 & 2: 4 \mathrm{I} \\ 25 & 2: 94 & 35 & 2: 35 \\ 26 & 2: 88 & 36 & 2: 30 \\ 27 & 2: 82 & 37 & 2: 24 \\ 28 & 2: 76 & 38 & 2: 19 \\ 29 & 2: 70 & 39 & 2: 13\end{array}$


Om t. ex. en person, som ingăr vid sitt 25:e år, under första försäkringsåret afsätter $I_{5} \mathrm{kr}$., så utfaller, om han aflider redan under detta år, (1 5 X 2,94) $44 \mathrm{kr}$. I6 öre; fortsätter han nästa år och då inbetalar ytterligare $20 \mathrm{kr}$., så ökar han härigenom försäkringssumman med $(20 \times 2,88)$ $57 \mathrm{kr}$. 60 öre, sả att han nu är försäkrad för IOI kr. 70 öre. Genom ny insättning under nästa år, ökar han ytterligare sin försäkringssumma, o. s. v.

För unga personer speciellt är detta försäkringssätt synnerligen fördelaktigt. Försäkrar sig någon vid t. ex. 18 år och genom köp af sparmärken gör en årlig insättning af $\mathrm{t}$. ex. 20 kronor, så utgör hans försäkringssumma vid 28 års ålder $672 \mathrm{kr}$. 80 öre, hvilka utbetalas vid hans död. Han har på detta sätt billigt och bekvämt skaffat sig en försäkring på $678 \mathrm{kr}$. 80 öre, för hvilken han ej vidare behöfver betala ett öre.

Denna arbetareförsäkring, som man lämpligast kunde kalla sparförsäkring, har, som sagdt, stort släkttycke med postsparbanken.

Äfven för anstalten är detta försäkringssätt fördelaktigt, ty den s. k. matematiska risken är genom fondafsättningens storlek bragt till en minimum, som fallet alltid är vid premiebetalningar en găng för alla.

Slutligen tillåtes det mig. anmärka, att skall i vårt land arbetareförsäkring af hvad form det vara må kunna vinna någon anslutning och därjämte verka välsignelsebringande, är det nödvändigt, och helt visst af större vikt än för andra omrăden inom försäkringsväsendet, att en verksam försäkringslagstiftning kommer till stånd, som förhindrar, att arbetare lockas in $\mathrm{i}$ försäkringsföretag af tvifvelaktig natur.

\section{N. V. E. Nordenmark.}

\section{Några ord om fackföreningar och storstrejk.}

Frågan om arbetarnes föreningsrätt och speciellt om den nuvarande norrländska săgverksarbetarefrågan behandlades i det förra häftet af Ekonomisk tidskrift dels $\mathrm{i}$ form af en kritik af professor Hjärnes föredrag och en af mig utgifven broschyr och dels genom meddelande af ett par bref från en af de norrländska arbetsgifvarne. Då alla hithörande spörsmål för närvarande äro aktuella, kan det måhända tillătas mig att göra ett nytt inlägg, hvilket icke är ämnadt att vara ett genmäle $\mathrm{i}$ vanlig bemärkelse, utan snarare ett uttalande $i$ en pågående diskussion. Jag vill således förbigå mycket, som tidskriftens redaktör anfört gent emot mig, helt enkelt därför att jag anser det olämpligt att oupphörligt beröra samma saker, 